\title{
Research on the Deep Integration of Education in Information Technology Institutions
}

\author{
Wei Shen ${ }^{1, a}$ and Lei Wang ${ }^{2, b^{*}}$ \\ ${ }^{1}$ College of Computer Science and Technology, Beihua University, Jilin, China \\ ${ }^{2}$ The personnel department, Beihua University, Jilin, China \\ aabyswabysw@163.com, ${ }^{\text {b}} 513636202 @ q q . c o m$
}

Keywords: Information technology; Undergraduate education; Deep convergence; Local colleges and universities

\begin{abstract}
The rapid development of information technology, which is changing people's mode of living and studying, is now penetrating into the field of higher education. Its combining with teaching practice results in fundamental change in teaching thoughts, systems and methods. The deep impact on undergraduate education and teaching developments has to catch our attention.
\end{abstract}

\section{Introduction}

The Internet and emerging information technologies such as cloud computing, big data, the world's fastest innovation, versatility and the penetration of the strongest one of high technology, is profoundly affecting higher education teaching ecology. Especially in recent years, large-scale online open courses such as the rise of new online open courses and learning platform, expand the teaching time and space, to enhance the attraction of teaching, expand benefited range for high quality education resources, has been and is promoting undergraduate teaching contents, methods, mode and the management system reform. We must seize this important opportunity, closely around khalid ents fundamental task, accelerate the information technology and teaching of undergraduate course depth fusion, education informationization promoting modernization of education, further improve the level of teaching and talent training quality.

Has the advantages of disciplines and the modern education technology advantage and the related departments of colleges and universities, to actively organize online open courses development and construction high quality, on the basis of meet the demand of students learning, let more towards the national excellent courses, through collaborative group of integration to build high quality online courses, to enrich the teaching of higher education resources. Depth at the same time, the information technology into the undergraduate teaching reform, through developing teachers' information technology application ability training, to strengthen the inspection to supervise and promote the informationization teaching, virtual reality technology, digital simulation experiment, online knowledge support, online teaching monitoring is widely used. Using information technology such as large data, master the different students' learning needs and regularity, accurate delivery of teaching resources, to promote students' personal development.

Sound management system is the important guarantee of information fusion technology and depth of teaching of undergraduate course. Must adhere to the student as this, toward to arouse teachers' participation, elementary students initiative in the direction of the perfect, the key is to explore to establish online open courses teaching resources and learning system. Growth pattern to follow the law of education teaching and talent, and gradually establish and improve the relevant systems, especially the building will be the school that online open courses into the plans for training scheme and teaching system, teachers' related calculation workload evaluation system, exploring students enrolled in the online open course credit authentication method, online learning, and the combination of classroom teaching credit authentication and transformation method, make students have more opportunities to learns a higher quality of teaching resources. In addition to promoting online teaching content and teaching method reform, take the initiative to adapt to the characteristics and needs of the contemporary college students, strengthen interaction, according to 
their aptitude, promote the students' autonomous learning, must put students in thinking, promote the thinking and thinking about the situation of test, pay attention to cultivate students' creative thinking and practical ability of solving the problem.

Education innovation is the key mechanism innovation, the breakthrough is innovative talents training mechanism in colleges and universities. This is the third plenary session of the 18 in higher education reform, development and put forward the most direct, the most clear requirements, is the top priority of the current comprehensive deepening of higher education reform. Media higher personnel training, for example, media institutions joint academic organization, industry enterprises, the online education alliance, founded the Chinese media and art can be said to be the cross-regional cross-industry cross cross major in colleges and universities, talent cultivation mechanism set up an important platform for innovation media, shows a strong endogenous driving force and dynamic. Members in colleges and universities based on win-win cooperation concept, based on the principle of complementary advantages, based on their respective comparative advantages, vigorously promote the development and demand, the theory and practice, scientific research and teaching, the close combination of internal resources and external resources. Mutually by JiaoJiao synergy, strive to promote the teacher, the student swaps, elected course, mutual recognition of credits; He, the school, the school together, accurate revision training objective, accurate, perfect curriculum system, teaching team, precise, accurate advance internship practice, in education and improve the teaching level, cultivate more high-quality innovative talents.

\section{Discussion}

Information technology application in the teaching activities can not only improve the quality of teaching, also help students' all-round development, the depth of the fusion has become the main development direction in the information technology in the subject teaching, to fully realize the depth of fusion, the first thing we should deal with and to redo the course content, abundant learning resources for the students to make it through the modern teaching means such as multimedia, enhance image cognition, actively participate in teaching activities, and stimulate students' interest in learning, improve teaching effect.

\section{Information technology and subject teaching depth fusion}

Depth fusion specific refers to the integration of information technology effectively in subject teaching, make the subject teaching and information technology to form a unified whole, and then complete the teaching mission, strengthen students' independent analysis and problem solving skills, to cultivate the students' information gathering, processing, and innovation ability. Its essence is the reform of teaching structure, practice aims to fusion, to optimize the teaching effect. To fully realize the goal of depth fusion, we increased the exploration in practice, constantly develop the teaching resources, improve teaching modes, and obtained a certain result.

In the informatization environment, put forward higher request in the subject teaching, students' learning patterns and means of acquiring knowledge must be changed, too. In the face of the ever-changing information technology, how to give full play to the role of the information technology in the subject teaching has become the main task of the teaching workers. For the comprehensive integration goal, we should learn and teaching mode innovation, promote group cooperative learning mode, strengthening the construction of software and hardware facilities.

\section{Create classroom wisdom}

Turn in the classroom, on the basis of our further innovation, finally to create the wisdom of classroom. Classrooms every month to carry out a classroom with wisdom as the theme of the research lesson, at the same time, should also be to disclose their research results in the whole school, classroom wisdom mainly contains the following modules.

Class for students to provide the corresponding curriculum resources, specific include learning task card, micro lesson, learning effect test card. Students on the basis of learning task CARDS can be autonomous learning in the home, library, etc, once encounter a problem, can ask the teacher or students through the network.

By learning effect test card, wait for completion of autonomous learning, can immediately detect 
preview effect, and then clear understanding the knowledge of the situation. For the problems of students' autonomous learning process, teachers should carefully organizing, record the representative problems, and group discussion in class, will eventually problem solving.

the surrounding teachers carefully selected inside the team collaboration to develop study question discussion, in this process, students can act as a teacher's role, to help other students solve problems; Second, the task to carry out the discussion around the classroom inquiry, if the group internal cannot be solved, can ask other team to help. In addition, teachers should guide and ensure the independent inquiry activity smoothly.

Through the practice to consolidate test platform, and on the basis of test results, learning situation, at the same time, teachers should also be fully grasp the progress of the students' autonomous learning, can according to the actual situation, the appropriate guidance. At the same time, students should also make full use of this tool for know note, carefully recording class notes, in order to deepen our memory.

\section{The development of curriculum resources}

With the advancement of new curriculum reform, the inadaptability and limitations of existing teaching resources is increasingly outstanding, on the one hand, can't satisfy the personalized needs of teachers, on the other hand, the lack of the cultivation of student's subjectivity, unable to meet modern personnel training standards. This requirement, teaching workers should actively develop curriculum resources, and expand the teaching resource, realize sharing. After a period of exploration, developed a small class the teaching resources, not only promote the teachers' professional level, also enrich the teaching resources. Teachers and students are up in the air free download of teaching resources, and stored in the terminal equipment, the mobile learning into reality.

\section{Build academic platform}

On the basis of digital campus, the effective fusion of the new development of curriculum resources and the creation of the wisdom of the classroom, on the basis of class feedback, specific research topic, build a research platform.

Reasonable choice course partners, forming course team, after being clear course tasks, with the help of field communication network resources or, write teaching design, teaching design and upload. This is mainly in order to create a good atmosphere of the entire school teachers participate in optimizing courseware, especially for the new teacher, to be able to play a positive role in guiding.

Team grinding. Research team should be timely rectification teaching design, and then uploaded to the net, and the academic team of team should accept the rectification opinions of their course, adjust and perfect the teaching design, and then upload to teaching design. This link is mainly in the campus teachers create research atmosphere, to achieve the goals of new curriculum reform of new teaching lay a good foundation.

Informationization special-purpose classroom is the main place to hold classes activities, including research team personnel should be the full, can listen to the teacher through the network, the rest of the teachers in the process of listening to lectures should be personal comment in time, also can comment at the end of the course. In schools to carry out the "criticism and self-criticism", to make teachers judge each other, so as to complement each other, will be excellent teaching. Tradition on campus learning methods and teaching mode, improve the effect of the informationization teaching.

Teaching reflection can help teachers' professional skills and the improvement of teaching level, this requires personnel shall accept modestly peer advice, thinking, summarizing, writing teaching reflection, and ensure the quality, uploaded to study the net, for reference. Only constant reflection, can keep good experience, unreasonable or inappropriate methods, will do a good job and concept, create a good teaching model.

Practice shows that the depth of the information technology and subject teaching integration not only fundamentally change the teaching idea, also improved the relationship between teachers and students to increase the communication between teachers and students, enhance the effect of 
classroom teaching, to achieve the win-win situation of teachers' teaching and students' learning, cultivate the students' logical thinking ability and innovation ability, improve the students' subjective initiative, and advance the construction process of quality education.

\section{Conclusion}

To sum up, in the subject teaching in information technology, not only can stimulate students' interest in learning, can also exercise the students' logical thinking, improve the students' subjective initiative, also can improve the students' cultural quality. And the rapid development of information technology to promote the integration of it with discipline teaching process, the fusion of the two is a long-term process, therefore, in the concrete practice, we should actively explore, effective to master the latest theory and method, and fully realize the goal of further integration.

\section{Acknowledgements}

The authors wish to thank the Jilin Province Education Science Planning Project (GH170278)、 (SJJY201719)、(ZD17022), under which the present work was possible.

\section{References}

[1] Lucia Naldi, Mattisa Nordqvist. Entrepreneurial Orientation, Risk Taking, and performance in Family Firms[J]. Journal of the family firm institute, 2007(1):33-47.

[2] Emest L Boyer. Schlarship Reconsidered: Priorities of the Professoriate. Princeton: The Camegie Foundation for the Advancement of Teaching, 1990.

[3] Wallmark J T, McQueen D H, Sedig K Q. Measurement of output from university research, a case study[J]. Engineering Management, IEEE Transactions, 2008, 3:175-180.

[4] Youtie J , Shapira P. Building an innovation hub: a case study of the transformation of university roles in regional technological and economic development[J]. Research Policy, 2008, 37(8): 1188-1204.

[5] Geenhuizen M V, Soetanto D P. Academic spin-offs at different ages: A case study in search of key obstacles to growth[J]. Technovation, 2009, 29(10):671-681.

[6] Fini R, Grimaldi R, Santoni S, et al. Complements or substitutes? The role of universities and local context in supporting the creation of academic spin-offs[J]. Research Policy, 2011, 40(8): 1113-1127.

[7] Information on http://www. people. com. cn/GB/32306/33232/14743200. html

[8] Information on http://www. ox. ac. uk/about/oxford - people/famous - oxonians

[9] Anders Lundstrom, Lois Stevenson. Entrepreneurship Policy:Theory and practice[M]. New Mexico, Springer, 2005.

[10] Nabi G, et al. From student to entrepreneur: Towards a model of graduate entrepreneurial career-making[J]. Journal of Education and Work, 2010, 23(5):389-411.

[11] Nabi G, et al. From student to entrepreneur: Towards a model of graduate entrepreneurial career-making[J]. Journal of Education and Work, 2010, 23(5):389-411.

[12] Youtie J , Shapira P. Building an innovation hub: a case study of the transformation of university roles in regional technological and economic development[J]. Research Policy, 2008, 37(8): 1188-1204.

[13] Wallmark J T, McQueen D H, Sedig K Q. Measurement of output from university research, a case study[J]. Engineering Management, IEEE Transactions, 2008, 3:175-180.

[14] Emest L Boyer. Schlarship Reconsidered: Priorities of the Professoriate. Princeton: The Camegie Foundation for the Advancement of Teaching, 1990.

[15] Fini R, Grimaldi R, Santoni S, et al. Complements or substitutes? The role of universities and local context in supporting the creation of academic spin-offs[J]. Research Policy, 2011, 40(8): 1113-1127. 
[16] Information on http://www. people. com. cn/GB/32306/33232/14743200. html

[17] Information on http://www. ox. ac. uk/about/oxford - people/famous - oxonians

[18]Lucia Naldi, Mattisa Nordqvist. Entrepreneurial Orientation, Risk Taking, and performance in Family Firms[J]. Journal of the family firm institute, 2007(1):33-47.

[19] Anders Lundstrom, Lois Stevenson. Entrepreneurship Policy: Theory and practice[M]. New Mexico, Springer, 2005.

[20] Geenhuizen M V, Soetanto D P. Academic spin-offs at different ages: A case study in search of key obstacles to growth[J]. Technovation, 2009, 29(10):671-681.

[21] Information on http ://www. chinahr. com/news/

[22] Information on http ://www. ntu. edu. tw/chinese

[23] Information on http://www. cyut. edu. tw

[24] Information on http://cpc. people. com. cn/ 